\title{
SUSTAINABLE USE OF LOW COST BUILDING MATERIALS IN THE RURAL INDIA
}

\author{
Ali Haider Jasvi ${ }^{1}$, D.K. Bera ${ }^{2}$ \\ ${ }^{I}$ M.Tech Scholar, School of Civil Engineering, KIIT University \\ ${ }^{2}$ Asst. Professor, School of Civil Engineering, KIIT University
}

\begin{abstract}
This paper emphasises on the methods of using low cost housing technique in India. It provides us a challenge to use the natural materials and their by-product so as to reduce the wastage or bye products obtained from industries and environmental pollution. Various natural materials with their property, advantages disadvantages, and their availability have been discussed. The main challenge is to use the materials in structural component for low cost housing and their adaptation to factors like - technical, social, ecological, physical - through different products. It encounters the idea about the need of housing in rural India and explains different uses of materials and the techniques of building construction for LIG people, urban poor's in different aspects of building. It covers the use of local materials in the different components of building to make the building low cost and it makes an affordable houses for low income people.
\end{abstract}

Keywords: natural materials, low cost techniques, low income group, structural component. $* * *$

\section{INTRODUCTION}

Basic need of man in today's world is food, clothing and shelter. House construction is a dream for low income people in our India. Whether he is a farmer, labour or private employee. Cost of construction is at high because of high wages and high material cost. A poor man has to spend his entire life in construction a house [1]. Low cost housing is reasonable for low income owners, if they can invest $30 \%$ of their household income. India as a developing country, has $20 \%$ of high income population that can afford a house [2]. High and middle income people takeover most of the low income housing [3]. There is a need of cost effective construction technology and materials. A low cost housing doesn't mean to sacrifice with strength or build with operational materials but it means effective use of local materials and techniques that are durable and require less maintenance. Low cost material reduce the cost by using alternative techniques [2].

India's urban population is the second largest in the world. The country needs a plan for land acquision and rapid construction. $40-45 \%$ is slum population which is growing day by day [4]. Current shortage of 17.6 million houses is being faced by India [5]. Mumbai is the largest populated city of India having a population of 16 million according to 2011 census which has seen an increment of $15.98 \%$ from 2001 census [6].

India's population grows by $1.3 \%$ per annum which is a main problem as $37 \%$ of population is below poverty line [7]. A need of using low cost and easily available materials and technology. Shortage of 17.6 million houses generates the usage of local available and natural materials in rural and urban India. According to World Bank the rural and urban population of India in 2013 is $67.97 \%$ and $32.02 \%$ respectively [8], [9].

\section{BODY OF THE PAPER}

In a country like India, where population is very high and the number of houses are few to accommodate, it's very important to use the alternate housing methods and materials to fulfil the demand.

\subsection{TECHNIQUES}

Too understand the techniques better, building should be divided into different parts like roof, walls, floor, and foundation.

\subsubsection{ROOF AND FLOOR METHODS}

\subsubsection{Filler Slab}

A filler lab material may be a waste material, used to ensure advantage over RCC slab [10,5]. Used in India, but mostly in South India.[10].Simple and innovative technique for roof construction. Steel is good in tension and concrete in compression. Difficult to remove concrete from tension zone but can be replaced using a filler material. Materials are placed in such a way that strength is not comprised, thereby removing unwanted concrete from below, hence reducing the material and increasing the economy, saving cost, and reduction in dead load; for more advantage internal cavity wall can be provided. Different materials used as filler material like Mangalore tiles, coconut shells, etc. [1012].Advantages are cost effective, improved thermal coefficient, reduction in carbon emission by $20 \%$, and better appealing, material recycled [10], [11], [12].Before deciding the design of slab, filler material should be decided. Size of filler decide the depth of slab and spacing of reinforcement. Filler should be soaked in water so as it does not absorbs water from concrete [11]. 
Prof Ing Peter Hayek et al. states that installing filler materials made up of plastics and recycled non-sorted plastic acquired from municipal waste can be used in shells. Refer table 1 for comparison between convectional and filler slab [10].

M P Jaisingh et al. researched on filler slab using cellular concrete blocks as filler and stated that in two-way continuous slab there is a reduction of $16 \%, 44 \%$, and $17 \%$ of cement, steel, and cost; where as in a one way continuous slab a reduction of $33 \%, 46 \%, 25 \%$ can be obtained. [10,13].

\subsubsection{Brick Panel Roofing}

Developed by CBRI, Roorkee. IS14142:1994, IS 14143:1994 used for its design. The concrete is used in high compressive zone where as bricks are used in less compressive zone. Use of $\mathrm{M}_{20}$ grade or 1:3 grade cement mortar used for construction. Method use for making brick panels and precast joist. Made up of first class bricks reinforced with $6 \mathrm{~mm}$ MS bars. Length varies from 900$1200 \mathrm{~mm}$ but width is kept $530 \mathrm{~mm}$ for allowing $36-40 \mathrm{~mm}$ gaps between bricks. To increase the length of brick panel diameter of bars is also to be increased [14].Suitable for rural areas.

Advantages are saving in cement, steel, labour, time and cost, concrete and centring cost can be saved by $20-25 \%$ and $25-35 \%$ of complete slab cost respectively. [15,11].A factory can produced approximately 1,20,000 brick panels/day in an 8 hour shift and 24,000 RCC joist in an annum. Compressive strength ranges up to $150 \mathrm{~kg} / \mathrm{cm}^{2}$. Standard size of brick panel is $1200 \times 530 \times 75 \mathrm{~mm}$ and that of RCC joist is $130 \mathrm{x} 00 \times 3600 \mathrm{~mm}$. Compressive strength of brick panel is $150 \mathrm{~kg} / \mathrm{cm}^{2}$. The number of skilled and unskilled labour required are 6 and 20 respectively [15]. Bick panel weights $75 \mathrm{~kg}$ whereas RCC joist weights $15 \mathrm{Kg} / \mathrm{m}$. [11].

\subsubsection{Flat Slab}

Slab that is directly supported on columns without any intermediate beams. Constructed in 1906 by Turner in the USA by using some of the basic theoretical designs. Testing of different slabs was done during 1910-1920. But Nicholas in 1914 gave a basic design method for its construction, but Jacob S Grossman's method of equivalent frame method with equivalent beam is preferred by engineers to calculate the analysis of work [16].

Different methods came into existence for different types like for small designs, empirical method can be used; for irregular frames, sub frame method can be used; calculation of reinforcement details, yield line method can be use. For slab spanning 5-9m thin flat slab should be preferred, whereas slab spanning more than $9 \mathrm{~m}$ post tensioning should be done. [17]

Advantages are easy form working, less construction time, easy concreting, [16,18]. Despite of all these advantages Indian engineers have to use ACI - 318 because of IS 456:
2000 limitations [16].Disadvantage if is, it is prone to high earthquakes. [18].

Leonhard et al. studied flat slab by spread on seismic load on a model of two span supported by columns, three specimen were tested having one internal and two external joints, these models were subjected to identical horizontal cyclic load by increasing target displacement with different vertical slab loading. The result showed an increase in vertical load will cause overturning moment and horizontal replacement $[18,19]$.

Pan et al. studied flat slab which had external joints including $27 \mathrm{H}$ shape specimen under seismic loading and concluded that the higher dead load, higher will be the deflection $[18,20]$. Tegos I A et al researched related to deformability of internal slab column joist and concluded that the study refers to seismic behaviour of joints and internal drift of multi storey structure. [18,21].

\subsubsection{L\&T Flex Table System}

A better type of form work used to lay RC floor. Used for heights up to $5.8 \mathrm{~m}$. Different prop sizes can be used like CT - 250, CT-300, CT-340, CT-410. Prop nuts are used for height adjustments. Flat slab construction is done using this method. No bracing requirement. Smooth finishing of concrete is available. In flat slab, 0.8 man hours $/ \mathrm{m} 2$ is required [22]

\subsubsection{WALL CONSTRUCTION}

\subsubsection{Soil Stabilized Block}

In compressed block walling, cement is used as a stabilized soil to obtain wet strength. Other stabilizer can also be used but they do not satisfy the requirement of economically and readily availability. It is uneconomical to use cement of mortar $15 \mathrm{~kg} / \mathrm{m}^{2}$ of walling. One method of stabilization is compacting the soil to reduce void, thereby increasing the density and compressive strength and reducing the ingress of moisture of block [23].The other method of producing brick can be done by using AURAM press 300 built in AVEI, India in 1989. The equipment can produce 125 blocks/hour and at a single stretch it can put 17 moulds making 75 blocks. Refer table $2 \& 3$. [23,25].

The constituents of soil cement stabilization used are $50 \%$ sand, $15 \%$ gravel, $15 \%$ silt and $20 \%$ clay and that of lime stabilization is $15 \%$ gravel, $30 \%$ sand, $20 \%$ silt, $35 \%$ clay $[24,29,25]$.Lime and cement are costly additives but locally available; but if not properly worked out can give disappointing results [23]. In case of sandy soil, cement is used. Cost of this block is $19.4 \%$ less than fired bricks and $47.2 \%$ less than wire cut bricks [25].Advantages of the block are high and thin walls can be constructed, high compressive strength and water resistance, transferable technology, and eco-friendly.Disadvantages are due to cement stabilization curing shall be done for 4 weeks, identification of soil is required, skilled labour required [25]. 


\subsubsection{Hollow Concrete Block}

Expensive as there is arequirement of graded sand and large quantity of cement i.e. $12-17 \%$ by weight. If properly dimensioned; can be laid on $10 \mathrm{~mm}$ mortar joint. Vibrating table is required to settle the mix. To compress the material a heavy lid is slammed many time [23].

Hollow concrete blocks are replacements of stone and convectional bricks. They are easy to place, and lighter than convectional bricks. In demand by different department like housing board, PWD, forest department, road transportation [26]. Standard size of hollow brick are 400x200x100mm, 400x200x150mm, 400x200x200mm [26,15]. These blocks have a compressive strength of $39-147 \mathrm{KN} / \mathrm{m}$. Different machines are used for construction of these blocks like hand held type block machine, stationary block machine, standing type block machine [15]

Advantages are good quality, less labour required, durable. Uses are interior and exterior walls, retaining walls, compound walls [26], [27].

\subsubsection{Rat Trap Bond}

Masonry technique, where bricks create cavity in wall having same wall thickness as that of convectional concrete. In rat trap bond brick are placed on edge forming outer and inner face of wall with cross bricks [5]Cement mortar used is of 1:6. In an 8 hour shift, 0.3 million tiles/annum can be produced. Manpower required are 1.6 man-days of skilled, 4 man-days of unskilled, and 0.5 man-day of labour for $1 \mathrm{~m}^{3}$ of masonry. [15]Main advantages are less number of bricks are used [5], $80 \%$ of reduction of load on foundation, same strength as compared to other bricks, up to 3 storey can be built [15].

\subsubsection{Thin Joint Construction}

The method is used mostly in Europe and UK [28].It is asubstitute practice to $10 \mathrm{~mm}$ sand and cement mortar. Supplied as dry-premixed powder in $25 \mathrm{Kg}$ bags which is applied with special spreader of $3 \mathrm{~mm}$ thick. Sets within $10 \mathrm{mins}$ and complete strength is gained within 1-2 hours.Approach is different to cement and sand system. All blocks need to be cut according to specific dimension [29]. A mechanic saw, circular saw is used instead of bolster chisel or club hammer as it would cause greater joint than $3 \mathrm{~mm}[29,28,30]$.

First course laid on DPC. The course should be allowed to set over night and levelled before instigation with thin joint construction. Regular checks of plumb, line, and level are needed [29]. Refer table 4, 5\& 6.

Different sizes of block are available like 610x140x200mm, $610 \times 215 \mathrm{~mm} 610 \times 270 \mathrm{~mm}$ having various thickness used for cavity walls; all are manufactured in high strength, standard, and solar grades [28].25Kg of cement and 5.75L of water is mixed in a bucket. Electric mixing tool is used for maintaining the consistency of the mortar. Four hour workability should be achieved for mix. Special scoop is used for scattering the mortar of $3 \mathrm{~mm}$ thickness. Mortar should be plastic for $6-9 \mathrm{~min}$ and set within $10 \mathrm{mins}$.Benefits can enhanced by using jumbo blocks of $440 \mathrm{~mm}$ length and $430 \mathrm{~mm}$ height [29].

Used in partition wall, cavities walls, solid walls and separating walls [29, 30]. Advantages are high bond strength, accurate dimension blocks, easy mixing of quantities, high sound insulation and fire resistance $[28,30]$

\subsubsection{Fly Ash Sand Lime Bricks}

A Sumanthi et al. had done an research to determine the best possible mix design for making fly ash sand lime brick, he conclude that the best possible mix shall be $15 \%$ fly ash, $30 \%$ lime, $21 \%$ gypsum, and $53 \%$ quarry dust having a compressive strength of $7.91 \mathrm{~N} / \mathrm{mm}^{2}$ at 28 days. Increase in fly ash content, decrease in compressive strength. The water absorption for the mix is $10.9 \%$ which is less than the standard value of $12 \%$ where the brick size is of 230x110x90mm [32]

Tayfun Cicek et al. had done an experiment on the different constituents of fly ash sand lime bricks, stated that with the increase in content of quartz sand, the strength increases from $2.2-3.74 \mathrm{~N} / \mathrm{mm}^{2}$, the highest compressive strength of $3.74 \mathrm{~N} / \mathrm{mm}^{2}$ is obtained at $40 \%$ quartz sand addition, also found out that the highest compressive strength of $4.75 \mathrm{~N} / \mathrm{mm}^{2}$ was obtained at $12 \%$ lime, with increase in the lime content no extra strength is obtained [33].

Size of the bricks is $230 \times 115 \times 75 \mathrm{~mm}$ using volcanic ashes $60 \%$, sand $20 \%$, lime $15 \%$, and gypsum $5 \%$, production capacity of 1.8 million bricks/annum of eight hours working time in two shifts. Equipment used are brick making machine, pan mixer and mould. Land required is 2000 \& $150 \mathrm{~m}^{2}$ of open and covered area respectively, 4 and 20 skilled and unskilled labours respective.Advantages are ecofriendly, accurate dimension, reduce shrinkage, and use of industrial waste [15].

\subsubsection{Aerated Concrete Blocks}

Aerated autoclaved concrete blocks was first developed by a Swedish engineer between the year 1920-32 [34,36]. Since 1980 , increase in the use of AAC materials in different parts of the world like India, Australia, Bahrain, China etc. In 1996, North America opened the first plant a more than 420 factories around the globe produce it $[34,36]$. Aerated concrete is a type of light weight concrete which neglects the routine of coarse aggregates and includes high percentage of void. A foaming agent is applied in the mix before the materials are poured in the moulds. Density is reduced to $500 \mathrm{Kg} / \mathrm{m}^{3}$ [23].Size of the block is $600 \mathrm{~mm}$ long, 100-300mm deep, 300mm high. One AAC block weighs $12.23 \mathrm{Kg}$ where as one CMU block weighs $15.4 \mathrm{Kg}$, AAC blocks create $1.3 \mathrm{ft}^{2}\left(13.98 \mathrm{~m}^{2}\right)$ of wall area whereas CMU block creates $0.88 \mathrm{ft}^{2}\left(9.46 \mathrm{~m}^{2}\right)$ of wall area. The first course is laid in traditional mud block and subsequent course is laid with a thin layer of jagged trowel [35]. 
Ahmed Aidan et al. investigates the production and characteristics of high quality AAC and the results suggest that AAC blocks are fifth the weight of concrete, having sand absorption quality, breathable wall system [34]. Refer table $7 \& 8$.

Advantages are high wall area/block, low thermal conductivity, less moisture penetration [23], lighter than convectional concrete blocks [35].Disadvantages are not suitable for heavy load bearing conditions, process is complex which is unsuitable for small scale manufacture [23], fragile, water absorbent at surface, not aesthetically pleasant [35].

\subsubsection{OTHER TECHNIQUES}

\subsubsection{Aluminium Formwork / Mivan Formwork}

One of the most advanced system which has less maintenance and high durability, this formwork can be used anywhere. The entire procedure has to be planned first. Slab, column, and wall can be casted together, saving extra time. The panels are made by aluminium are light weight, easy to handle, strong. They can be used with a repetition of 250 times or more and if not then it is costly. The component of this formwork are aluminium rail, section panels and sheets. Having a thickness of $4 \mathrm{~mm}$ skin plate and $6 \mathrm{~mm}$ ribbing to stiffen the panel. The manufacturing of these formwork are specially done in South East Asia and Europe. After placing the order the shipment is received within three months [37].Advantages are less labour, fast construction, reuse of panels, custom design formwork [37], seismic resistance, less maintenance, no tower cranes required [38].Disadvantages are finishing lines can be seen, planning should be done before construction, less modification due to casting is one, shrinkage cracks may appear [37].Suited for high and low rising building. Rate of construction estimated to be 4 days/floor [38].

\subsubsection{Tunnel Form Work}

Tunnel formwork is a steel formwork that is used to cast wall and slab monolithically. It can be of different size, shape and modulus $[39,41]$. Tunnel formwork are basically of two types, one is classical tunnel formwork which consist of half or full tunnel form work; second is railed tunnel formwork [42]. Either half or full form work can be used or construction, it depends upon crane capacity and width of the form. Half tunnel form are used for wide span and full tunnel are used for short span rooms [40]. Mostly used in UK [41].Internal size of cell is 2.4-6.6m wide which can be divided into smaller rooms. The code used is BS 8100 for one way slab. On an average a team of eight plus a crane driver is required who can fix $300 \mathrm{~m}^{2}$ of formwork each day including placing of $35 \mathrm{~m}^{3}$ of RMC [41].40-45\$ $/ \mathrm{ft}^{2}$ of form work contact area is the cost of tunnel form work including all accessories and heating system. This can be re used for 500-100 times [40].

Advantages are time effective as floor to floor construction can be done in one to three days, independent on climate condition, high precision of 1/1000 deformation is allowed, can be used 800 times [39,41], less error [40], speed construction, earthquake resistant, no finishing required, reduction in frame cost by $15 \%$ and saves time by $25 \%$ $[41,42]$.Disadvantages are increase in the formwork cost $/ \mathrm{m}^{2}$ for small construction, cost of equipment is high because of requirement of crane, cannot be used for music halls or theatre, basement cannot be constructed, minimum thickness of wall is $20 \mathrm{~cm}$, continuous or mat footing needed [39], work cannot be done in high winds [41]. Use for hotels, house prison, barracks [41].

\subsubsection{Gypsum Area Separation Wall}

Gypsum walls are lighter in weight, easy to construct, less time consuming. Gypsum wall provide one to three hour fire resistance rating, sound isolation $[43,44,45]$. Code used are Building Officials \& Code Administrators International Inc and Southern Code Congress International. In these codes gypsum wall are also called party walls, fire walls or town house separation wall.The requirement of UBC is that each unit should have one hour rating for exterior walls with no openings if the property line is within three feet $(0.91 \mathrm{~m})$. No need of parapet wall if area of floor is less than $1000 \mathrm{ft}^{2}\left(10760 \mathrm{~m}^{2}\right)$. Two hour rating is needed for separate portion of structure. Gypsum is non-combustible in nature and has been used since 100 years as plaster of Paris. Main content of gypsum is calcium sulphate dehydrate which contains $21 \%$ chemically combined water by weight. When subjected fire, water is released as steam. This process protects the other side from high heat [43].Main content of gypsum board are one inch thick non-combustible type $\mathrm{X}$ gypsum liner panel, metal naming, and break away aluminium clips which softens at relatively low temperature [43]. Gypsum area separation wall consist of metal framing of I or $\mathrm{H}$ studs spaced on 24 inch centre to centre, panels are inserted into the studs and supported with flanges [44].Products quality is assured for every unit by third party certification and labelling. [45]

Advantages are panel weighs 8 to 9 pounds/ $/ \mathrm{ft}^{2}(0.33$ $\left.0.37 \mathrm{~kg} / \mathrm{m}^{2}\right)$, more space available, scaffolding not needed, less use of labour and material. Meets various codes requirement like BOCA, ICBO, and SBCCI, thickness of wall is 2-4 inch [43], easy usage up to four storeys [45].Disadvantages is it cannot be used in high humid conditions like indoor pool, saunas etc. and also cannot be used in temperatures more than $52^{\circ} \mathrm{C}$. [15]

\subsubsection{GFRG Panel Building System}

GFRG is particular significant to India, where there is a need of cost effective construction technology. The product is eco-friendly as well as fire resistant [46].GFRG panel system are also known as rapid wall or gypcrete $[46,48]$. Used in both load bearing and non-load bearing structure. Having modular cavities which are suitable for internal and external wall. Also be used for roof slab/floor slab with RCC. Invented in Australia in 1990 [47]. Panel size of $12 \mathrm{~m}$ length, $3 \mathrm{~m}$ high, $124 \mathrm{~mm}$ thick, 48 cavities of $230 \times 94 \times 3 \mathrm{~mm}$ in each panel, $1440 \mathrm{Kg}$ weight of each panel, $10-12 \%$ light as 
compared to brick/concrete masonry [47]. The glass fibre length of $300-350 \mathrm{~mm}$ is used having fibre content of $0.8 \mathrm{Kg} / \mathrm{m}^{2}$ [48].Pile, raft, spread foundation is used for this type of construction. Basement plinth consist of RCC plinth beam [47]. IS 456:2000 is used for designing, for earthquake resistance IS 1893 (part 1):2002 should be used [46].Table 9: physical and material properties of panels and table 10 for comparison bet convectional and rapid wall building.

$\mathrm{Yu}$ Fei $\mathrm{Wu}$ at al. states that the lateral resistance of GFRG concrete filled wall comes from two different action, one is from shear resistance of rapid wall and the second is the lateral resistance of internal reinforced concrete core [46].

$\mathrm{Wu} \mathrm{Y} \mathrm{F} \mathrm{et} \mathrm{al.} \mathrm{had} \mathrm{carried} \mathrm{a} \mathrm{shear} \mathrm{and} \mathrm{axial} \mathrm{load} \mathrm{test} \mathrm{for}$ GFRG wall panel of $2.85 \mathrm{~m}$, width of the panel was 1.52 and $2.02 \mathrm{~m}$ for shear test and $1.02 \mathrm{~m}$ for axial load test, the result stated that under axial load filled panel failed due to flexure tensile and buckling, whereas unfilled panel failed due to plaster crushing, irrespective of eccentric axial load. He also states that there are to shear failure i.e. shear failure of panel itself and shear sliding between floor slab and interface wall $[48,50]$.

Advantages are dead load reduced by $50 \%$, carpet area increased by $8 \%, 15-20 \%$ reduction in construction cost, resistant to corrosion, termite [47], saving in materials, reduction in $\mathrm{CO}_{2}$ emission [49].Disadvantages is in low seismic zones, ten storey can be built [46].

\subsection{Materials}

Materials can be classified into manmade and natural materials. Materials like bagasse, rice husk, banana leaves, coconut husk, are natural available from the remains of agriculture industry [7]. Materials like fly ash, ferro cement are an example of man-made materials which can be recycled to make new product that help in low cost construction [1].

\subsubsection{Natural Materials}

Fibres are hair like materials which are discrete elongated pieces like threads [51]. Paintable, attractive, cheaper, rotresistance. Having low density and eco-advantages over other composites their nature is lingo cellulosic. Natural fibre have a potential to replace glass fibre. But the main dis-advantage is water absorption, therefore chemical treatments is required [52]

\subsubsection{Bamboo Fibre}

Bamboo being the second largest production in the world after China. India grows around 50\% of world's total share. Around 9.57 million hectare are covered in India [7].

Swaptik et al. stated that the tensile strength of bamboo is around $650 \mathrm{~N} / \mathrm{mm}^{2}$ and that of steel is $500-1000 \mathrm{~N} / \mathrm{mm}^{2}$. Bamboo is more flexible than steel having low modulus of elasticity of $50 \mathrm{GPa}\left(50000 \mathrm{~N} / \mathrm{mm}^{2}\right)$ than that of steel [7]. The readily availableness and rapid growth has made bamboo a structural material in the area like India, China and Japan [53,7]. G Leake et al. stated that the upper class of Colombia uses concrete but in India upper class uses stone, middle class uses wood, and lower class uses bamboo for construction [53].

Mechanical properties of bamboo varies from specimen to specimen. It can be used in beams rather than in columns as it will buckle. One of the major problems is connection of bamboo culms [54]. It can be used for bamboo roofing sheet which is strong, durable, light weight and fire resistance.

\subsubsection{Earth}

One of the oldest material but due to its limitation like erosion, water penetration, termite attack and high maintenance it is less used. But this limitation can be overcome by

1) Compressed earth block - developed from adobe block or also known as earth block. Consist of cement using manual press.

2) Non - erodible mud plaster - Its constituents are bitumen which is mixed with a specific mud paste. Has the ability to resist water [3]

\subsubsection{Straw fibre}

The early use of straw was by Mesopotamian and Egyptian in 1500 BC. Straw has provided reinforcement to ancient products like boats and pottery [55]. After the removal of chaff and grain, straw is obtained which is one of the byproducts of agriculture industry. Toughest compared to other straw. Burning causes breathing problems, so an alternate method is needed for it deposition. [3]

\section{Applications}

1) Life extended thatch roof - environmental friendly. It is fire resistant and water proof [7]

2) Improved thatch roof - CBRI has designed a technique to make the roof more fire and water resistant by plastering the layer by mud to make it more resistant to fire [7]

\subsubsection{Bagasse fibre}

Obtained from the remains of sugarcane or sorghum stalks. Waste quantity is same as the quantity of production. Around 500 sugar mills are present in India [3]. It is pale green to grey yellow in colour. It is non-uniform and bulky in size.

A Balaji et al. states that approximately $50 \%$ cellulose and $25 \%$ of both lignin and hemicellulose is present. If properly modified, shows better mechanical properties. $85 \%$ of the material is burnt or deposited on field [56].

Advantage is low energy input, eco-friendly, reduces the density of product [56].Disadvantages is less impact strength stocking problem, degradation of fibre etc. [56]. It can be used as bagasse cement board and panels, bagasse PVC boards, biomass power generation [3]. 


\subsubsection{Jute and Coir Fibre}

It is a vegetable fibre [57]. Cultivation of jute started around $800 \mathrm{BC}$. It has been spread in many parts of India. 33 districts which have $98.41 \%$ of total area under jute cultivation [3]. Jute is mostly used for packaging [58].From the husk of coconut, coir is obtained [52]. Two third production comes from India. Its durability is because of presence of linin. It is grown around 10 million hectare in tropics. It has a length of $35 \mathrm{~cm}$ and a diameter of $12-25$ microns. Coir industry is located in India, Brazil etc. [59].Jute and coir fibres are used to produce coir - CNSL board, jute coir composite, coconut and wood chips roofing sheet, geo textiles etc. $[3,57,60]$.

\subsubsection{Sisal Fibre}

D. Chandramohan et al. stated these fibre are naturally available that have low price, high specific strength and are recyclable. It can be used as reinforcement to make reinforced polymer composite. Life span of sisal plant is 710 years which can produce 200-250 leaves. 1000 fibres, a leaf can produce [51]. This fibre cannot be used in places of wet spills, snow, and rain. But it can be used for paper production, cordage industry, tiles, geotextiles, roofing sheets, and cement flooring sheets [51], production of ropes [58].

\subsubsection{Banana Fibre}

Banana also called kalpatharu. India is the largest producer after Brazil. India has 5 lakh hectares of farms out of which $10 \%$ of waste is used to extract the fibre [61]. There is no particular method for extraction of banana fibre. It is a highly strong fibre, with small elongation, light weight, average fineness is about $2400 \mathrm{Nm}$, bio-degradable, environmental friendly [62].It is being used for the production of building boards, fire resistance boards, and medical applications, ropes, mats, home furnishes. [3, 62].

\subsubsection{Rice Husk}

Around 600 million tons of rice is produce every year out of which $20 \%$ is waste i.e. rice husk. Either the waste is dumped or burnt. Rice husk ash is produce during burning of rice husk. About $220 \mathrm{~kg}$ of husk is produce from $1000 \mathrm{~kg}$ of rice and around $55 \mathrm{~kg}$ of ash is produced if burnt. [63]20\% of the world's rice production is by India. West Bengal has highest production area but Punjab has highest productivity. Constituents of husk is $75 \%$ organic matter and $25 \%$ weight of husk which is converted to ash, $85-90 \%$ of silica is present in ash [3]. It is used in power plants, roofing units, rice husk binder, fibrous building panels, bricks, acid proof cement, production of activated carbon, thermal insulating bricks, production of some acids, production of building materials, low cost sandcrete block. $[3,63]$.

\subsubsection{Manmade Materials}

Industrial revolution created many by products that were a problem to dispose of. After a deep research upon their properties, it was observed that they had best pozzolanic properties. So these materials started been using as alternative materials. [3].

\subsubsection{Fly Ash}

Obtained from the burning of coal, and recovered from gasses. Major constituents of fly ash is iron, alumina and silica [3]. Fly ash generation has increase from 68.88 million tons/annum to 131.09 million tons/annum from 1996 to 2011. But the utilization is only increase by $6.64-73.13$ tons/annum i.e. about $14 \%$ [64].Fly ash can be used in fly ash brick, bulk fill, filler in bituminous mix, artificial aggregate [3].

\subsubsection{Aerocon Panels}

These are inorganic bonded sandwich panels consist of two fibre cement reinforced sheets. Made up of Portland cement, binders and a mix of micaceous and siliceous aggregates. These panels are eco-friendly, light weight, fire resistance, sound reduction properties etc. It has been used in one of the housing scheme in India under "VALMIKI" for slums. [3]

\subsubsection{Ferro Cement}

It a versatile cement based on the composite material made by cement mortar reinforced with one or more layers of wire mesh. It's a high performance, good strength material. The only dis advantage is high creep and shrinkage. Used for water tanks, cycle shed etc. as it is easy to build it can be used in post disaster management [3].

\subsubsection{Cement Concrete Hollow Bocks}

Cost effective and better alternative to burnt clay bricks. Has properties like fire resistance, durable, high speed of construction. As they are large in size less mortar is used. Strength can used enhanced as per requirement [3].

\subsubsection{Recycled Steel Reinforcement}

Steel can be used as a recycled scrap iron. Used in steel reinforced structures like building and bridges. Main criteria to be satisfied by the reinforcing bars is mass/meter run. Rolling tolerance in the range of $+/-7-3 \%$ depending on diameter is given by is 1786 . Wastage can be reduced if purchase in standard length, but if not 5-7\% may be wasted. Electrical melting recycled steel produces $40 \%$ of world steel. The advantages are high strength, bond strength, resistant to termite, weathering [7].

\subsubsection{Precast R.C.C}

These are door frames with welded reinforcement. Indian standard manufacturing. Durable, economical. Fire, corrosion and termite proof. No cracks, bending, shrinkage. Site installation is easy. Much stronger than other door frames. High strength to weight ratio than RCC and gives $20 \%$ saving on cost and materials [7] 


\section{ECONOMIC STUDY}

Filler slab is much more economical than traditional slab as it saves $16 \%, 44 \%, 17 \%$ of cement, steel and cost in twoway slab and $33 \%, 46 \%, 25 \%$ in one way slab respectively [10].

Brick panel saves $19 \%$ per $\mathrm{m}^{3}$ and Rs 418 in cement, $19 \%$ per $\mathrm{m}^{3}$ and Rs 21 in sand, $19 \%$ per $\mathrm{m}^{3}$ and $\mathrm{Rs} 127$ in aggregate, and $38 \%$ per $\mathrm{m}^{3}$ and Rs 536 in steel [11].

Soil stabilized bricks are $27.7 \%$ cheaper as compared to country fired bricks walls, where country fired bricks use Rs 934 per $\mathrm{m}^{2}$ there soil stabilized bricks use Rs 736 per $\mathrm{m}^{2}$, they are less air pollution, energy consumption, carbon emission [24-25].

Aluminium form work is a comparatively high cost construction but give high quality and speed construction which can be used in places where speedy construction is required.

GFRG building saves around 50.8\%, 35.2\%, and $27.47 \%$ of cement, steel and cost to convectional buildings [47].

Flat slab the total quantity of steel and concrete used are $8.644 \mathrm{~m}^{3}$ and $1294 \mathrm{~m}^{3}$ as compared to conventional building which uses $10593 \mathrm{~m}^{3}$ of steel and $1505.25 \mathrm{~m}^{3}$ of concrete and the cost saving percentage in flat slab is $15 \%$ in $B+G+3$ building respectively [78].

Hollow concrete blocks can be used in those places where the load is not coming directly on wall, the cost saving is by $17.78 \%$. [79].

Rat trap bond are much economical than convectional bricks. They reduce the usage of bricks by $25 \%$ andeee mortar by $40 \%$ [80], and reducing the load by $8 \%$ [15] while giving same compressive strength with a saving of $57 \%$ in cement cost, $20 \%$ saving in bricks, and $61 \%$ saving in sand [81].

\section{SOCIAL IMPACT}

New housing technology improves the eco system of the society. Improving housing methodology is essential. Housing is segregated either by design or location. It is very important that different income people interact with each other to develop the community, it can be done by mixed use development, mixed income development or co-housing.

\section{CONCLUSION}

Good housing is a need to every human being. Everyone wants to live in big houses which are comfortable. In urban areas there is a shortage of number of houses. People need houses that are attractive, having more life span, larger space area, environmental friendly and cheaper. Therefore cost effective houses and low cost houses are needed to fulfil the demand. The local available materials and technology serve a purpose for low income people. Using cost effective technology will not only save money but also reduce $\mathrm{CO}_{2}$ emission, save time and faster production. A cost reduction of $20-30 \%$ can be achieved by using alternative methods.

\section{NOTATION}

cm: Centimetre

${ }^{\circ} \mathrm{C}$ : Centigrade

ft: Feet

G Pa: Giga Pascal

grm: Gram

$\mathrm{kg}$ : Kilogram

KN: Kilo Newton

1: litre

m: Meter

mm: Millimetre

mins: Minutes

MJ: Mega Joules

$\mathrm{N}$ : Newton

rs: Rupees

$\%$ : Percentage

\$: US Dollar

\section{REFERENCES}

[1]. S. S. Shinde, A. B. Karankal, "Affordable Housing Materials \& Techniques for Urban Poor's”, IJSR, Volume 1 Issue 5, May 2013.

[2]. Vivian W. Y. Tam, "Cost Effectiveness of using Low Cost Housing Technologies in Construction", Elsevier, 2011, pp: $156-160$.

[3]. Oloruntoba, Kayode, Ayodele E Olusegun, "Local Building Materials: A Tool towards Effective Low - Income Housing in Nigeria", Journal of Scientific Research, Volume: 18, Issue: 4, 2013, pp: 492 - 497.

[4]. S. Deepak, V. A. Shanmugavelu, "Cost Effective Techniques Uses In Modern Construction Projects”, IJSR, Volume 3, Issue: 5, May 2014.

[5]. U. J. Phatak, C. S. Chavan, Lalit V. Rathod, "Cost Effective House by Using Various Construction Techniques and Materials", IJAR, Volume: 4, Issue: 4, April 2014.

[6].https://en.wikipedia.org/wiki/Mumbai_Metropolitan_Re gion

[7]. Swaptik Chowdhury, Sangeeta Roy, "Prospects of Low Cost Housing in India", Geomaterials,March 2013, Volume: 3, pp: $60-65$.

[8].http://www.tradingeconomics.com/india/ruralpopulationpercent-of-total-population-wb-data.html.

[9].http://www.tradingeconomics.com/india/urban-populatio n-percent-of-total-wb-data.html.

[10]. Amit D Chougule, Manoj H. Mota, Ushadevi S Patil, "To Study The Filler Slab as Alternative Construction Technology - A Review", Journal Of Information, Knowledge And Research In Civil Engineering, Volume: 3, Issue: 2, October 2015

[11].http://sepindia.org/ihd-sep/ceeef-technologies/filler-slab -technology/

[12]. http://arkistudentscorner.Blogspot.in/2011/05/fillerslab s.html 
[13]. M. P. Jaisingh, L. Jaisingh, B. Singh "A RC filler slab with non- autoclaved cellular concrete blocks for sustainable Construction",Central Building Research Institute, Roorkee.

[14]. Narendra Verma, V. K. Gupta, N. Singh, Balbir Singh "Building Research Note - 79", CSIR - Central Building Research Institute, Roorkee, January 2011.

[15]. "Environment Friendly Indian Building Material Technology for Cost Effective Housing", Society for Excellence in Habitat Development, Environmental Protection \& Employment Generation (SHEE).

[16]. S. S. Patil, Rupali A. Sigi, "Flat Slab Construction in India", IJEIT, Volume: 3, Issue: 10, April 2014.

[17]. "Flat Slabs for Efficient Concrete Construction", 2001.

[18]. George E. Lelekakis, Athina T. Birda, Stergios A. Mitoulis, Theodoros A. Chrysanidis, Ioannis A. Tegos, "Applications Of Flat Slab R/C Structures In Seismic Regions, Department of Civil Engineering, Aristotle University of Thessaloniki.

[19]. Leonhardt, F. - Monning, E, Regan, P. E., "Behaviour of Reinforced Concrete Flat Slabs," CIRIA Report No. 89, Construction Industry Research and Information Association, London, 1981.

[20]. Pan, A, and Moehle, J P, "Lateral Displacement Ductility of Reinforced Concrete Flat Plates", ACI Structural Journal, Volume: 86, Issue: 3, 1989, pp. 250 258 .

[21]. Tegos I A, Tsonos A G, "Repair and strengthening of slabs against punching shear", 12th Greek Conference on R/C structures, Lemesos, Cyprus, 1996.

[22]. "L\&T Formwork Moulding Imagination"

[23]. D E Montgomery, T H Thomas, "Stabilised Soil Research Progress Report SSRPR8", School of Engineering University of Warwick, March 2001.

[24]. Satprem Maini, "Compressed Stabilized Earth Block Sand Stabilized Earth Techniques Research and Development by the Auroville Earth Institute (AVEI)", November 2010.

[25]. "Compressed Stabilized Earth Blocks, A Modern technology".

[26]. Minato Shirke Concrete Machinery Pvt. Ltd "Hollow Concrete Block".

[27]. Ecologic Building System Private Ltd, "Advantages of Hollow Concrete Blocks".

[28]. The Celcon Thin-Joint System a Definitive Guide, February 2004, amended 2008.

[29]. Thin joint masonry, 80 Brickwork for Apprentices.

[30]. "Thin Joint Mortar Construction”, October 2011.

[31]. Construction Chemical and Mortar Technology.

[32]. A. Sumathi, K. Saravana Raja Mohan, "Compressive Strength of Fly Ash Brick with Addition of Lime, Gypsum and Quarry Dust", International Journal of ChemTech Research,Volume: 7, Issue: 1,2014, pp 28-36.

[33]. Tayfun Cicek, Mehmet Tanrıverdi, "Lime based steam autoclaved fly ash bricks", Construction and Building Materials, August 2006, pp: 1295 - 1300.

[34]. Ahmed Aidan, Zarook Shareefdeen, Bogdan Bogdanov, Irena Markovska, Dimitar Rusev, Yancho Hristov, Dimitar Georgiev, "Preparation and properties of porous aerated concrete", .Научни Трудове На Русенския Университет - 2009, том 48, серия 9.
[35]. Michael Chusid, "Building with autoclaved aerated concrete".

[36]. Elhaddad M.H, "Improvements of concrete properties to resist local climatic condition in the state of Qatar: research project”. P. 1- 4, 1993.

[37]. Patil Dhanashri Suryakant, Desai D B, "Emerging Trends in Formwork - Cost Analysis \& Effectiveness of Mivan Formwork over the Conventional Formwork", IOSR - JMCE, PP: 27-30

[38]. Kaivan Kazerouni, "Mivan Technology", July 2011, Avighna India Ltd.

[39]. Alaattin Kanoglu, "Tunnel Formwork System".

[40]. M. Wallace, "Cast Walls and Slab at the Same Time with Tunnel Forms", 1985.

[41]. "Cellular Construction Using Tunnel Formwork", Dunne Group Ltd, 2009.

[42]. Classic Tunnel Formwork and Railed Tunnel Formwork.

[43]. Robert A. Wessel, "Gypsum Board Area Separation Walls", December 1993.

[44]. Robert A Wessel, "Gypsum Area Separation Walls", January 1991.

[45]. "Gypsum Area Separation Firewalls", 2011.

[46]. Devdas Menon, A Meher Prasad, "Development of Building Systems using Glass Fibre Reinforced Gypsum (GFRG) Panels", Department of Civil Engineering, IIT Madras October 2013.

[47]. Glass Fibre Reinforced Gypsum Load Bearing (GFRG)Panels for Affordable Housing in Fast Track and Environmental Protection.

[48]. Maganti Janardhan, A. Meher Prasad, Devdas Menon, "Studies on the Behaviour of Glass fibre Reinforced".Department of Civil Engineering, Indian Institute of Technology Madras.

[49]. “Affordable Rapid Mass Housing”, July 2013, Department of Civil Engineering, IIT Madras, Chennai.

[50]. Yu Fei Wul and Mike P. Dare, "Axial and Shear Behaviour of Glass fibre Reinforced Gypsum Wall Panels: Tests", Journal of Composites for Construction, Volume: 8, Issue: 6, 2004, pp: $569-578$.

[51]. D. Chandramohan \& K. Marimuthu, "A review on natural fibres, IJRRAS, Volume: 8, Issue: 2, August 2011.

[52]. D. Verma, P. C. Gope, A. Shandilya1, A. Gupta, M. K. Maheshwari, "Coir Fibre Reinforcement and Application in Polymer Composites: A Review", JMESCN, Volume: 4, Issue: 2, 2012, pp: $263-276$.

[53]. G. Leake, C. Torres - Sánchez, K. Toole, P. Divis "Bamboo as a solution for low-cost housing and storage in Pabal (India)", Department of Design, Manufacture and Engineering Management, University of Strathclyde.

[54]. G. Leake, K. Toole, P. Divis, C. Torres-Sánchez, "Bamboo as a solution for low-cost housing and storage in Pabal (India)",University of Strathclyde, February 2010 [55]. K Sudhakar, Ch Srinivas, "Investigation of Mechanical Properties of Rice Straw Fibre Polypropylene Composites", IJERA, Volume: 4, Issue: 1, January 2014, pp: 182 - 187.

[56]. A. Balaji, B. Karthikeyan, C. Sundar Raj, "Bagasse Fibre - The Future Bio composite Material: A Review", International Journal of ChemTech Research, Volume: 7, Issue: 01, 2014 pp 223 - 233. 
[57]. https://en.wikipedia.org/wiki/Jute

[58]. W. D. Brouwer, "Natural fibre composites saving weight and cost with renewable materials".

[59]. http://www.naturalfibres2009.org/en/fibres/coir.html

[60].http://www.wigglesworthfibres.com/products/synthetic s/Jute\%20Yarn\%20and\%20Produ cts/usesofjute.html

[61]. http://www.ecogreenunit.org/projects/banana_ fibre_products.htm

[62]. http://www.teonline.com/knowledge-centre/bananafiber.html

[63]. Ajay Kumar, Kalyani Mohanta, Devendra Kumar, Om Parkash, "Properties and Industrial Applications of Rice Husk: A Review", IJETAE, Volume 2, Issue 10, October 2012

[64]. Md Emamul Haque, "Indian fly-ash: production and consumption scenario, IJWR, Volume: 3, Issue: 1, 2013, march 2013, pp: 22-25.

[65].http://www.gharexpert.com/a/ashishbatra/1658/RattrapBond_0.aspx

[66]. http://www.masonryframesystems.co.uk/the-mfssystem/thin-joint-blockwork/

[67].http://archrecord.construction.com/resources/conteduc/ archives/0303gypsum-1.asp

[68].https://www.mtm.kuleuven.be/Onderzoek/Composites/ people/LinaRocioOsorioSerna/Mi

crostructuralanalysisandmechanicalbehaviourofbamboofibre $\mathrm{S}$

\section{TABLES}

Table 1: comparison between convectional and filler slab [10]

\begin{tabular}{|l|l|l|l|l|}
\hline Slab & Item & Cement $(\mathbf{K g})$ & Steel $\left(\mathbf{K g} / \mathbf{m}^{\mathbf{3}}\right)$ & Cost $\left(\mathbf{R s} / \mathbf{m}^{\mathbf{2}}\right)$ \\
\hline \multirow{5}{*}{ Two-way } & $\begin{array}{l}\text { Convectional slab of 120 mm } \\
\text { thick }\end{array}$ & 38.4 & 71 & 415 \\
\cline { 2 - 5 } & Filler slab 150 mm thick & 32 & 4 & 346 \\
\cline { 2 - 4 } & Saving (\%) & $\mathbf{1 6}$ & $\mathbf{4 4}$ & $\mathbf{1 7}$ \\
\hline \multirow{3}{*}{ One-way } & $\begin{array}{l}\text { Convectional slab of 120 mm } \\
\text { thick }\end{array}$ & 48 & 6.5 & 450 \\
\cline { 2 - 5 } & Filler slab 150 mm thick & 32 & 3.5 & 338 \\
\cline { 2 - 3 } & Saving (\%) & $\mathbf{3 3}$ & $\mathbf{4 6}$ & $\mathbf{2 5}$ \\
\hline
\end{tabular}

Table 2: cement \& lime content in blocks [25]

\begin{tabular}{|l|l|l|l|}
\hline Description & Minimum & Average & maximum \\
\hline Cement stabilization & $3 \%$ & $5 \%$ & No max \\
\hline Lime stabilization & $2 \%$ & $6 \%$ & $10 \%$ \\
& & & \\
\hline
\end{tabular}

Table 3: Ecological comparison of building materials [25]

\begin{tabular}{|l|l|l|l|l|}
\hline Product and thickness & $\begin{array}{l}\text { No of units } \\
\left(\mathbf{p e r} \mathbf{~ m}^{\mathbf{2}}\right)\end{array}$ & $\begin{array}{l}\text { Energy } \\
\text { consumption } \\
\left(\mathbf{M J} / \mathbf{m}^{\mathbf{2}}\right)\end{array}$ & $\begin{array}{l}\mathbf{C O}_{\mathbf{2}} \text { emission } \\
\left(\mathbf{K g} / \mathbf{m}^{\mathbf{2}}\right)\end{array}$ & $\begin{array}{l}\text { Compressive strength } \\
\left(\mathbf{K g} / \mathbf{c m}^{\mathbf{2}}\right)\end{array}$ \\
\hline CSEB bricks $-24 \mathrm{~cm}$ & 40 & 110 & 16 & $40-60$ \\
\hline Wire cut bricks $-22 \mathrm{~cm}$ & 87 & 539 & 39 & $75-100$ \\
\hline Country fired bricks $-22 \mathrm{~cm}$ & 112 & 1657 & 126 & $30-50$ \\
\hline Concrete blocks $-20 \mathrm{~cm}$ & 20 & 235 & 26 & $75-100$ \\
\hline
\end{tabular}


Table 4: Fire resistance property of CELCON bricks (Euro code 6: Design of Masonry Structures: Part 1-2) [29,30] Fire resistance

\begin{tabular}{|c|c|c|c|c|c|c|c|c|}
\hline & Min & $\operatorname{Im~B}$ & Thic & $\mathbf{E x c}$ & Finis & & & \\
\hline & Loac & earin & all U & & Non & Bea & all $\mathbf{U}$ & \\
\hline Fire resistance (hours) & 1 & 2 & 4 & 6 & 1 & 2 & 4 & 6 \\
\hline Solar Range & 100 & 130 & 200 & - & 75 & 100 & 140 & - \\
\hline $\begin{array}{l}\text { Standard \& Hi strength } \\
\text { ranges }\end{array}$ & 90 & 100 & 190 & 215 & 75 & 75 & 100 & 150 \\
\hline Thickness (mm) & 100 & 100 & 190 & 215 & 100 & 100 & 100 & 150 \\
\hline
\end{tabular}

Table 5: Material specifications [31]

\begin{tabular}{|l|l|l|}
\hline Sr No & Description & Result \\
\hline 1 & Colour & Grey \\
\hline 2 & Component & $\begin{array}{l}\text { Portland cement, non - reactive aggregates, graded sand and } \\
\text { chemical additives }\end{array}$ \\
\hline 3 & Max aggregate size & $0.5 \mathrm{~mm}$ \\
\hline 4 & Water demand & Approx $26-28 \%$ or $10.4-11.2 \mathrm{~L} / 40 \mathrm{Kg}$ bag \\
\hline 5 & Density & $1.5 \mathrm{Kg} / \mathrm{L}($ dry) \\
& & Approx 1 hour \\
\hline 6 & Pot life & $2-3 \mathrm{~mm}$ \\
\hline 7 & Thickness & Approx $1.3 \mathrm{Kg} / \mathrm{m}^{2} / \mathrm{mm}$ \\
\hline 8 & Coverage & \\
\hline
\end{tabular}

Table 6: Technical specifications [31]

\begin{tabular}{|l|l|l|l|}
\hline Sr No & Description & Code Used & Values \\
\hline 1 & Fire resistance & BS 476: Part 22:1987 & $\begin{array}{l}264 \text { minutes fire } \\
\text { resistance at } 1,300^{\circ} \mathrm{C}\end{array}$ \\
\hline 2 & Compressive strength & $\begin{array}{l}\text { BS 6319 : Part 2:1983, } \\
\text { HKHA MTS (2002/2004) Spec. } \\
\text { Part D, Cl. 2.1.1 }\end{array}$ & $7 \mathrm{~N} / \mathrm{mm}^{2}$ \\
\hline 3 & Flexure strength & BS 6319: Part 3:1983 & $3 \mathrm{~N} / \mathrm{mm}^{2}$ \\
\hline 4 & Adhesive strength & JC/T 890:2001 & $0.3 \mathrm{~N} / \mathrm{mm}^{2}$ \\
\hline 5 & Shrinkage & JC/T 890:2001 & $<1.1 \mathrm{~mm} / \mathrm{m}^{2}$ \\
\hline 6 & $\begin{array}{l}25 \text { times freeze }- \text { thaw cycle } \\
\text { strength reduced }\end{array}$ & JC/T 890:2001 & $<20 \%$ \\
\hline
\end{tabular}

Table 7: Raw materials and typical amounts for production of AAC [34]

\begin{tabular}{|l|l|l|l|}
\hline \multicolumn{2}{|l|}{ Sr No } & Raw Materials & Per $\mathbf{~ m}^{\mathbf{3}}$ at $\mathbf{5 0 0} \mathbf{~ k g} / \mathbf{m}^{\mathbf{3}}$ dry density \\
\hline \multicolumn{2}{|l|}{} & With Sand & With Ash \\
\hline 1 & Sand $(\mathrm{Kg})$ & $320-340$ & - \\
\hline 2 & Cement $(\mathrm{Kg})$ & $65-75$ & $90-100$ \\
\hline 3 & Lime $(\mathrm{Kg})$ & $65-75$ & $50-60$ \\
\hline 4 & Gypsum (Kg) Anhydrite & 15 & - \\
\hline 5 & Aluminium (Kg) & $0.5-0.6$ & $0.5-0.6$ \\
\hline 6 & Water (Kg) & 230 & 250 \\
\hline
\end{tabular}




\begin{tabular}{|l|l|l|l|}
\hline 7 & Pulverised Fuel Ash $(\mathrm{Kg})$ & & $320-340$ \\
\hline 8 & Water For Steam $(\mathrm{Kg})$ & 140 & \\
\hline 9 & Fuel Oil $(\mathrm{Kg})$ & $11-12$ \\
\hline 10 & Electric Energy $\left(\mathrm{m}^{3}\right)$ & $13-16$ \\
\hline 11 & Mould Oil $(\mathrm{L})$ & 0.15 \\
\hline 12 & Grinding Balls $(\mathrm{Kg})$ & 1 \\
\hline
\end{tabular}

Table 8: Typical properties of aerated concrete (High pressure steam) [34]

\begin{tabular}{|l|l|l|l|l|l|}
\hline $\begin{array}{l}\text { Dry } \\
\text { Density } \\
\left(\mathbf{K g}^{\mathbf{3}}\right)^{-}\end{array}$ & $\begin{array}{l}\text { Grain size } \\
(\boldsymbol{\mu m})\end{array}$ & $\begin{array}{l}\text { Compressive } \\
\text { strength } \\
(\mathbf{N} / \mathbf{M M 2})\end{array}$ & $\begin{array}{l}\text { Flexural } \\
\text { strength } \\
(\mathbf{N} / \mathbf{M} 2)\end{array}$ & $\begin{array}{l}\text { Modulus of } \\
\text { Elasticity } \\
(\mathbf{N} / \mathbf{M} 2)\end{array}$ & $\begin{array}{l}\text { Thermal } \\
\text { conductivity at 3\% } \\
\text { moisture }\end{array}$ \\
\hline 450 & 70 & 3.171 & 0.621 & 0.016 & 0.12 \\
\hline 525 & 80 & 3.998 & 0.689 & 0.019 & 0.14 \\
\hline 600 & 90 & 4.481 & 0.827 & 0.027 & 0.16 \\
\hline 675 & 100 & 6274 & 1.034 & 0.025 & 0.18 \\
\hline 750 & 110 & 7.515 & 1.241 & 0.027 & 0.20 \\
\hline
\end{tabular}

Table 9: Physical and material properties of panels

\begin{tabular}{|c|c|c|c|}
\hline Sr No & Description & Value & Reference \\
\hline 1 & Density & $1.14 \mathrm{grm} / \mathrm{cm}^{3}$ & [46] \\
\hline 2 & Water absorption & $<5 \%$ & {$[46,48]$} \\
\hline 3 & Sound transmission & $\begin{array}{l}28 \text { (unfilled) } \\
45 \text { (filled) }\end{array}$ & [48] \\
\hline 4 & Elastic modulus & $3000-6000 \mathrm{~N} / \mathrm{mm}^{2}$ & {$[46,48]$} \\
\hline 5 & Thermal conductivity & 0.617 & [46] \\
\hline 6 & $\mathrm{U}$ - value & $2.85 \mathrm{~W} / \mathrm{M} 2 \mathrm{~K}$ & [46] \\
\hline 7 & Thermal resistant $(\mathrm{R})$ & $0.36 \mathrm{~m}^{2} \mathrm{~K} / \mathrm{W}$ & {$[46,48]$} \\
\hline 8 & Fire resistance & $4 \mathrm{hr}$ rating withstood $700-1000^{\circ} \mathrm{C}$ & [46] \\
\hline 9 & Ductility & 4 & [46] \\
\hline 10 & Tensile strength & $35 \mathrm{KN} / \mathrm{m}$ & {$[46,48]$} \\
\hline 11 & Flexure strength & $21.25 \mathrm{Kg} / \mathrm{cm}^{2}$ & [46] \\
\hline 12 & Unit shear strength & $50.9 \mathrm{KN} / \mathrm{m}$ & [46] \\
\hline 13 & Compressive strength & $\begin{array}{l}160 \mathrm{KN} / \mathrm{m}^{2} \text { (unfilled) } \\
1310 \mathrm{KN} / \mathrm{m}^{2} \text { (filled) }\end{array}$ & {$[47,48]$} \\
\hline 14 & Axial load capacity & $160 \mathrm{KN} / \mathrm{m}$ or 16 tons $/ \mathrm{m}$ & [46] \\
\hline 15 & Weight & $0.433 \mathrm{KN} / \mathrm{m}^{2}$ or $40 \mathrm{Kg} / \mathrm{m}^{2}$ & {$[46,47,48]$} \\
\hline 16 & Glass fibre & $300-350 \mathrm{~mm}$ long & [48] \\
\hline 17 & Fibre content & $0.8 \mathrm{Kg} / \mathrm{m}^{2}$ & [48] \\
\hline
\end{tabular}

Table 10: comparison between convectional and rapid wall building [46]

\begin{tabular}{|l|l|l|l|l|}
\hline Sr No & Materials & Convectional Building & Rapid wall Method & Saving in \% \\
\hline 1 & Cement & $32.55 \mathrm{Tons}$ & $16 \mathrm{Tons}$ & 50.8 \\
\hline 2 & Steel & $2779 \mathrm{Kg}$ & $1800 \mathrm{Kg}$ & 35.2 \\
\hline 3 & River Sand & $83.37 \mathrm{~m} 3$ & $20 \mathrm{~m} 3$ & 76 \\
\hline 4 & Granite Metal & $52.46 \mathrm{~m} 3$ & $38 \mathrm{~m} 3$ & 27.56 \\
\hline 5 & Bricks & 57200 & - & - \\
\hline 6 & GFRG Panel & - & $500 \mathrm{~m}^{2}$ & - \\
\hline 7 & Water & $200000 \mathrm{~L}$ & $50000 \mathrm{~L}$ & 75 \\
\hline 8 & Built Area & $154.45 \mathrm{~m}^{2}$ & $143 \mathrm{~m}^{2}$ & 8 \\
\hline 9 & Labour & $1200 \mathrm{man}_{\text {days }}$ & $389 \mathrm{man}_{\text {days }}$ & 67.59 \\
\hline 10 & Construction Time & 120 days & 21 days & 82 \\
\hline 11 & $\begin{array}{l}\text { Total Weight Of } \\
\text { Structure }\end{array}$ & 490 tons & 170 tons & 65 \\
\hline 12 & Construction Cost & 18.27 lakhs & 13.25 lakhs & 27.47 \\
\hline 13 & Energy Consumption & 215400 & 82921 & 61.5 \\
\hline
\end{tabular}




\section{FIGURES / PHOTOGRAPHS}
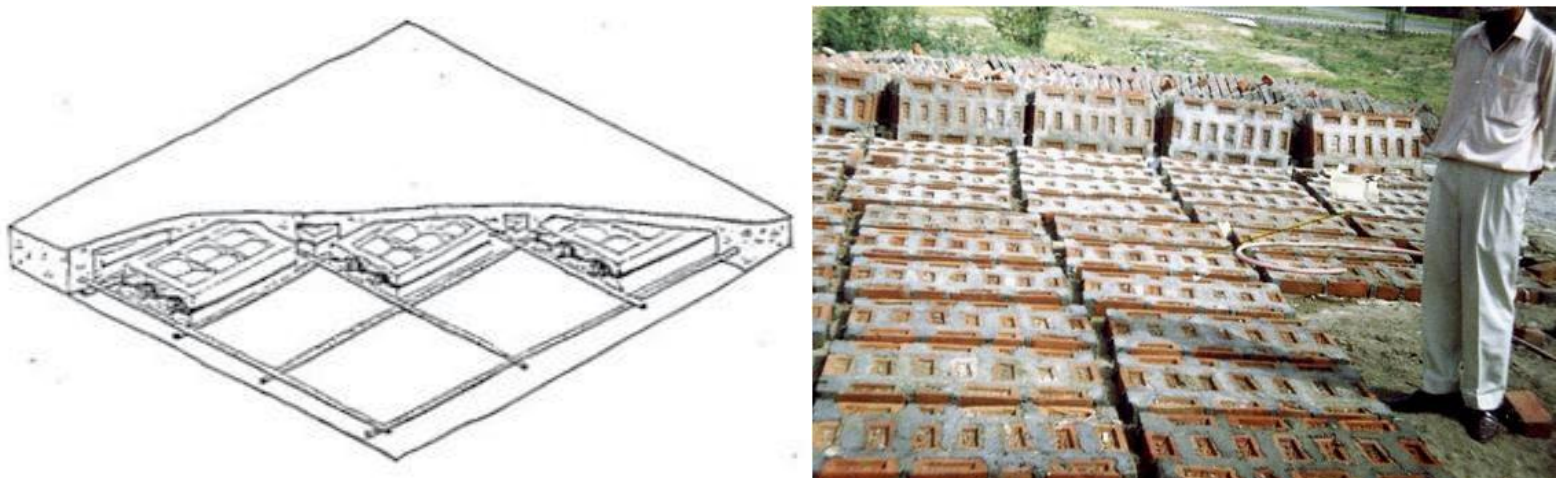

Fig 1: Reinforcement of filler slab [5]Fig2: A typical view of brick panel [15]

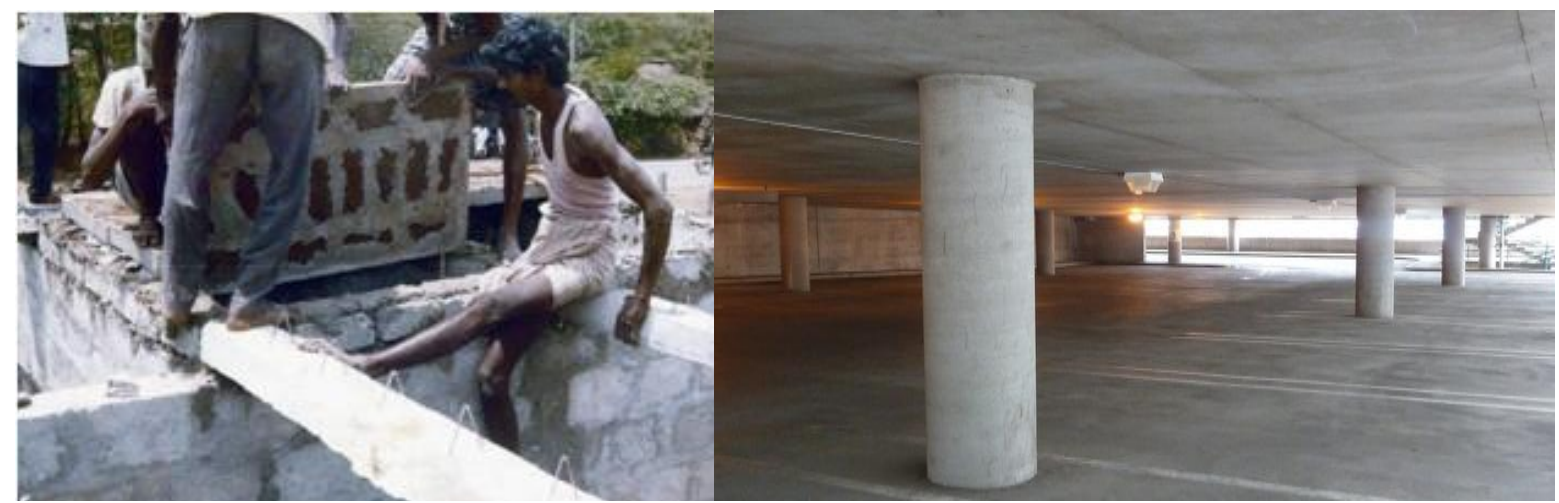

Fig3: Laying of brick panel [15]

Fig 4: A typical view of flat slab [16]

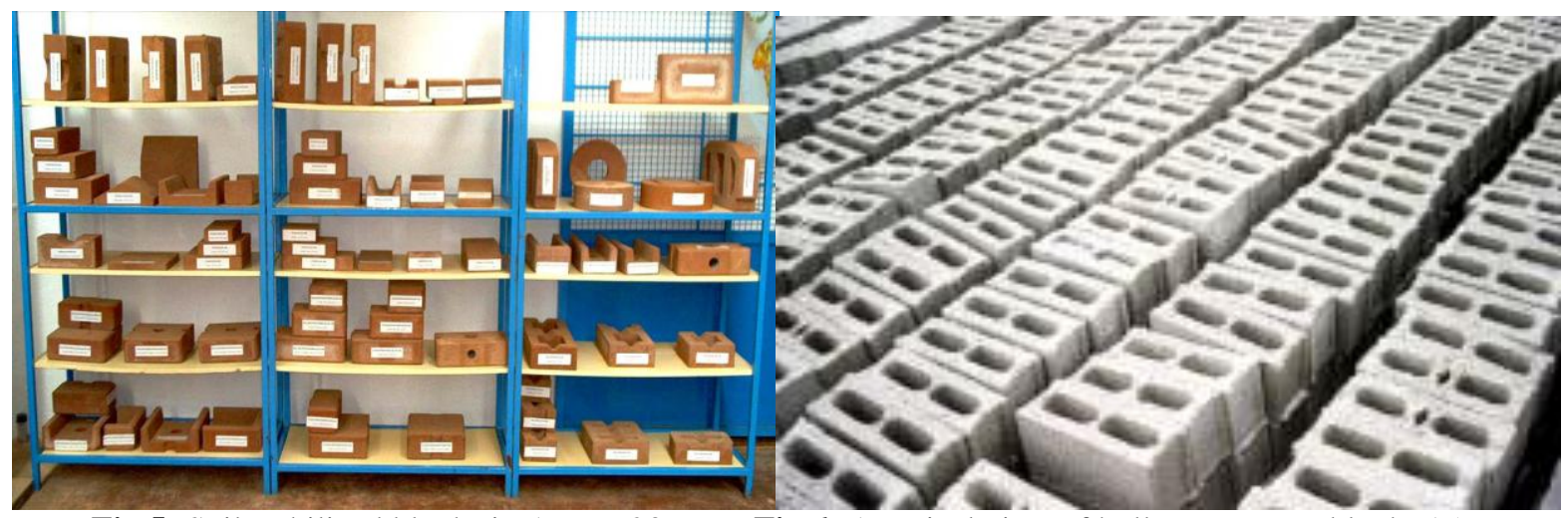

Fig 5: Soil stabilized blocks in AVEI [23] Fig 6: A typical view of hollow concrete block [15]
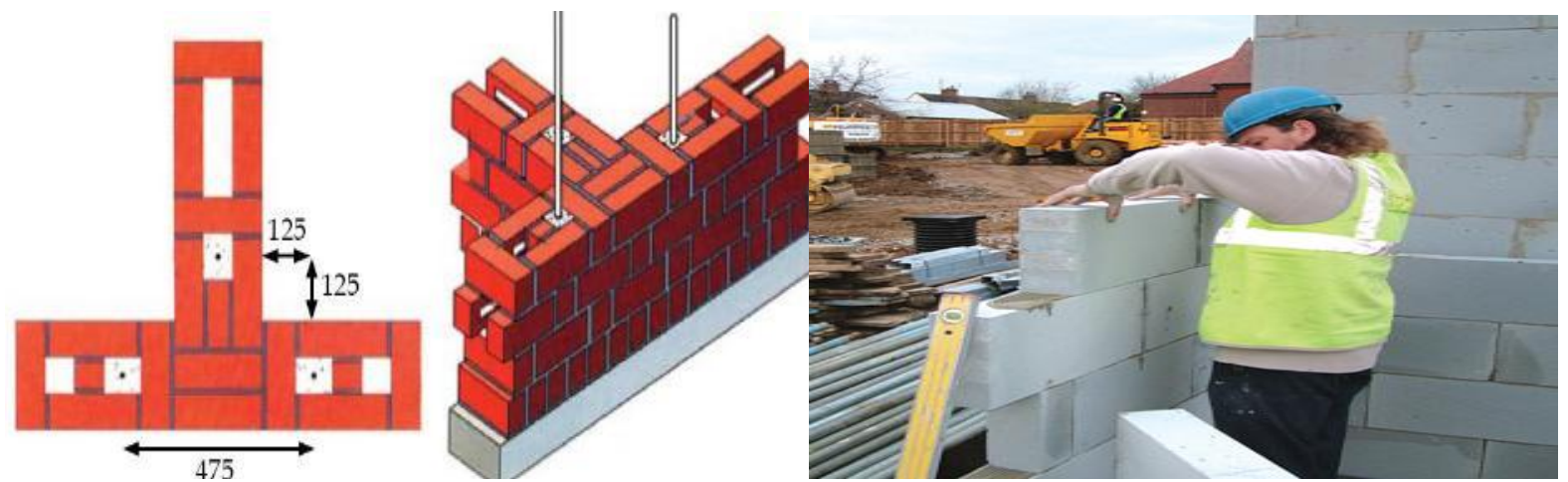

Fig 7: A typical rat trap bond [65] Fig 8: A typical thin joint construction [66] 


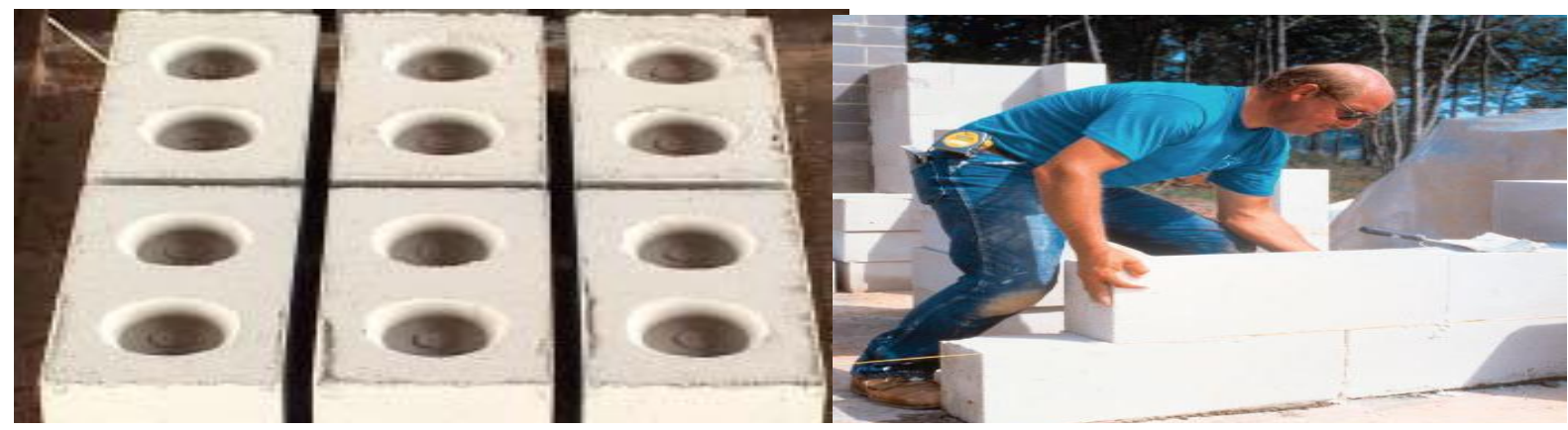

Fig 9: A typical view of fly ash sand lime Bricks [15]

Fig 10: A typical view of aerated concrete block [35]

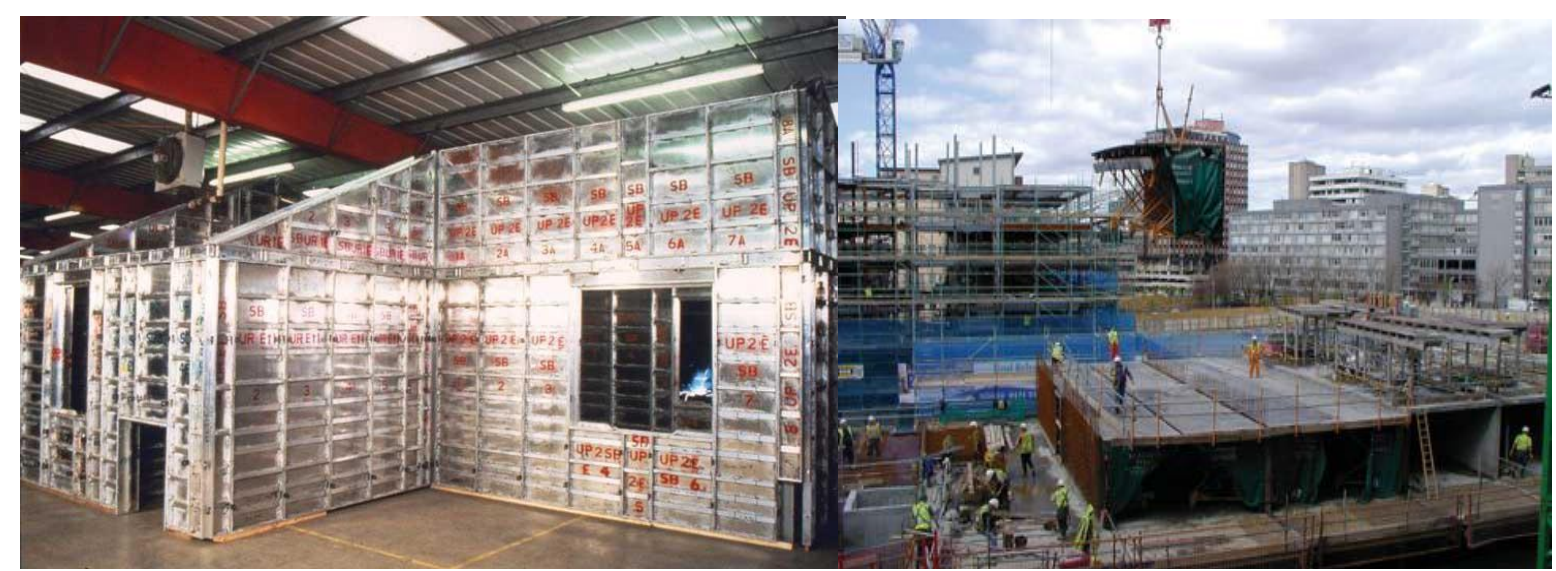

Fig 11: View of MIVAN formwork [37]

Fig 12: Tunnel formwork [41]
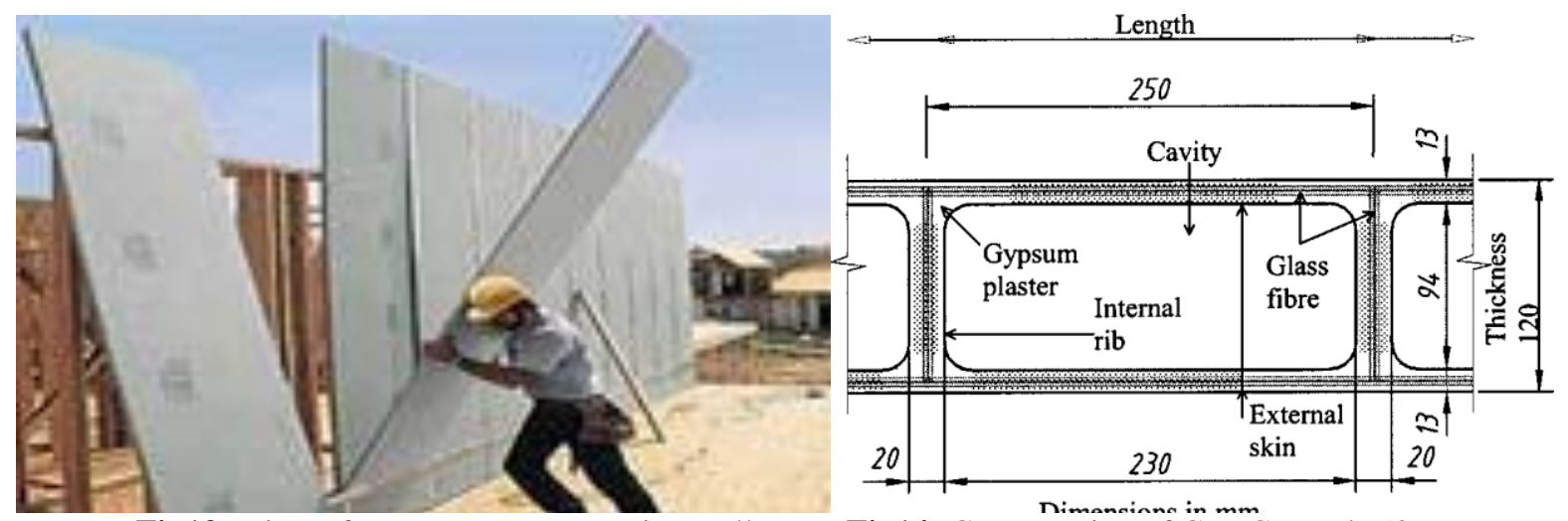

Fig13: View of gypsum area separation wall [67] Fig14: Cross section of GFRG panel [50]

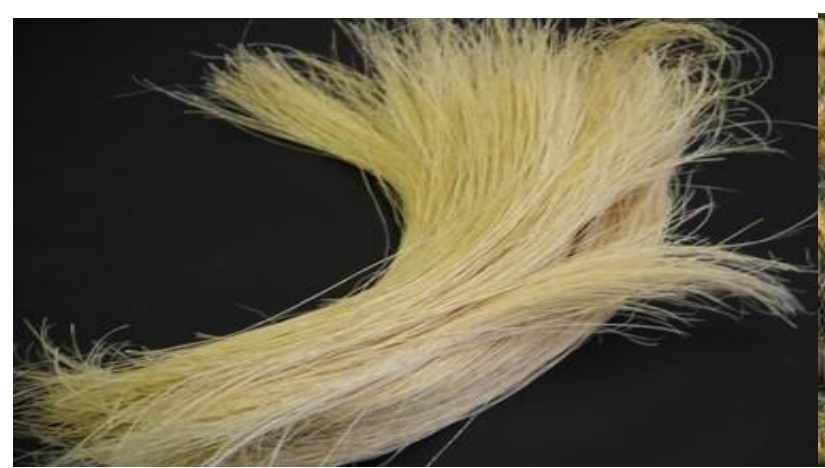

Fig 15: A typical view of bamboo fibre [68]

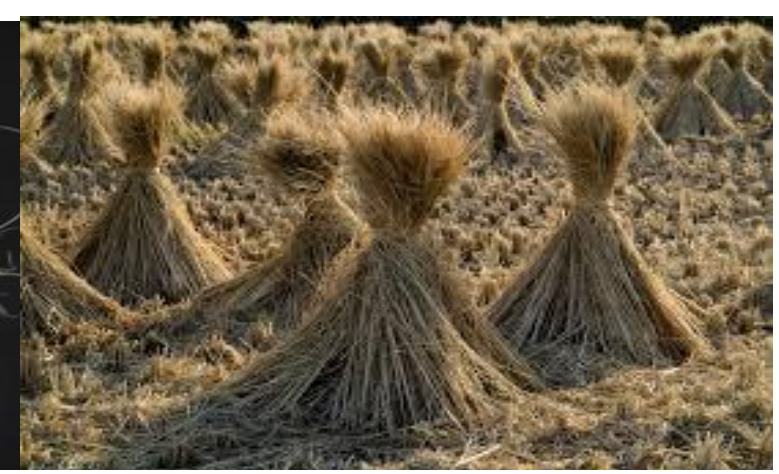

Fig 16: A typical view of straw fibre [69] 


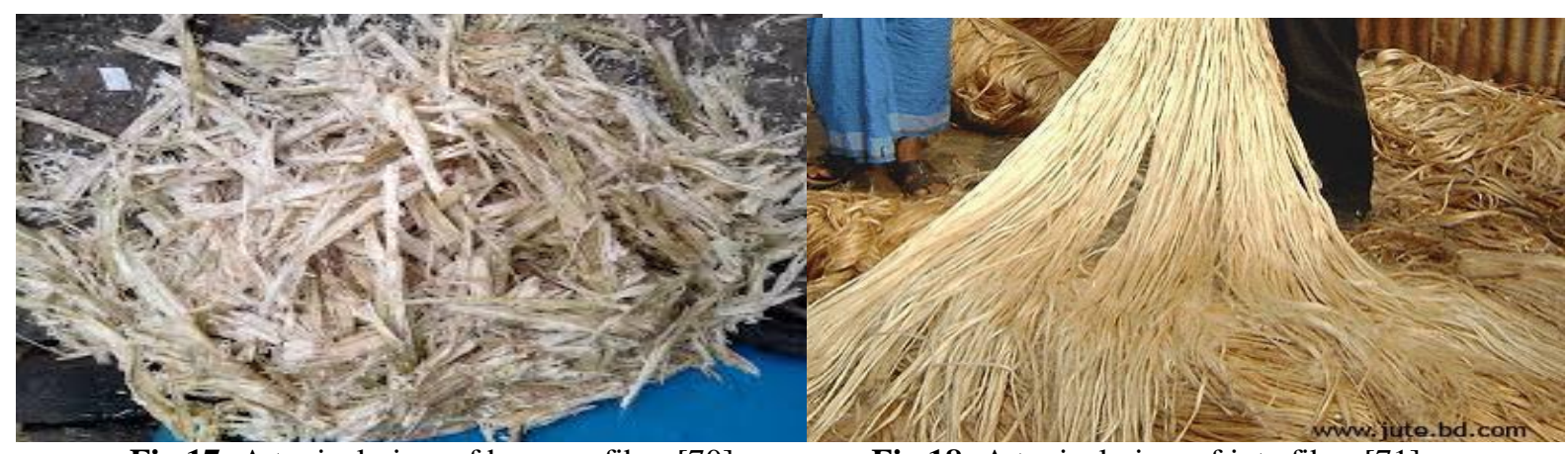

Fig 17: A typical view of bagasse fibre [70]

Fig 18: A typical view of jute fibre [71]

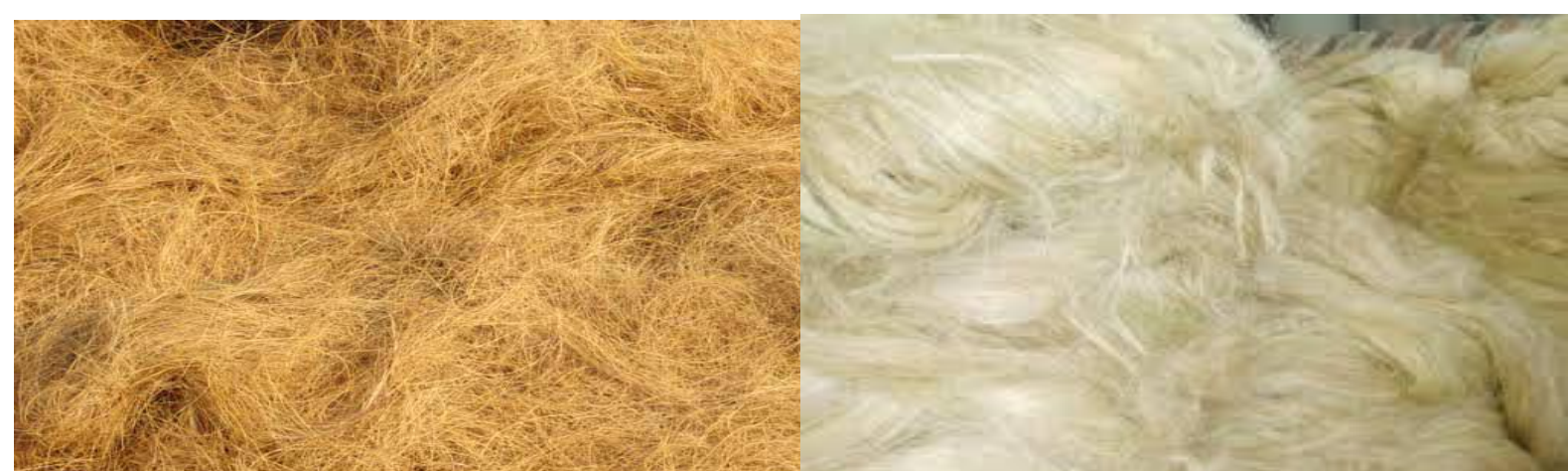

Fig 19: A typical view of sisal fibre [73]

Fig 20: A typical view of coir fibre [72]
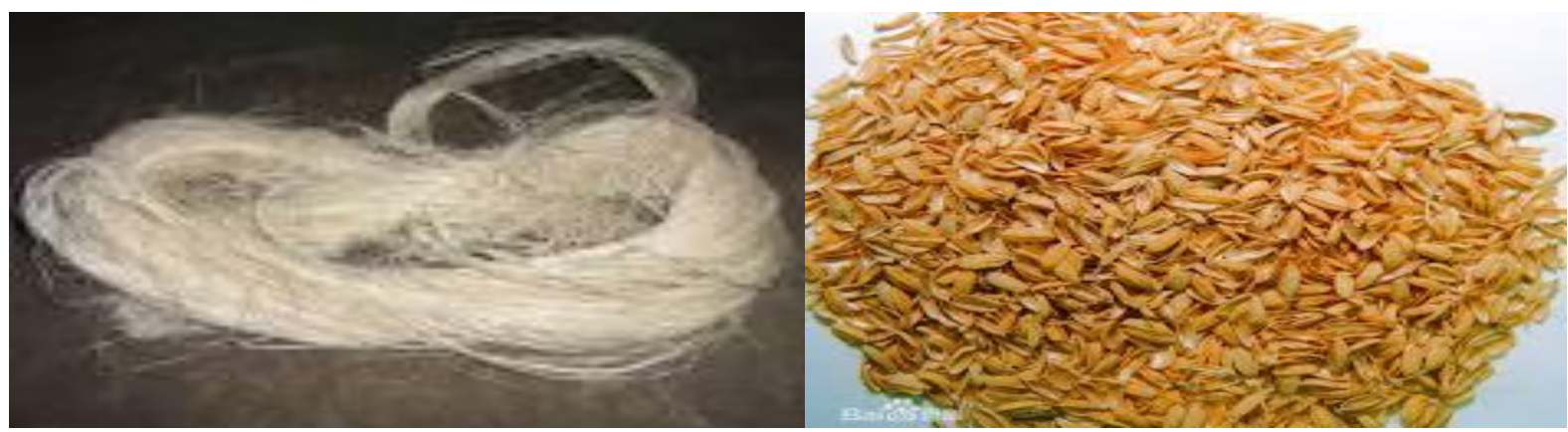

Fig 21: A typical view of banana fibre [74] Fig 22: A typical view of rice husk [75]

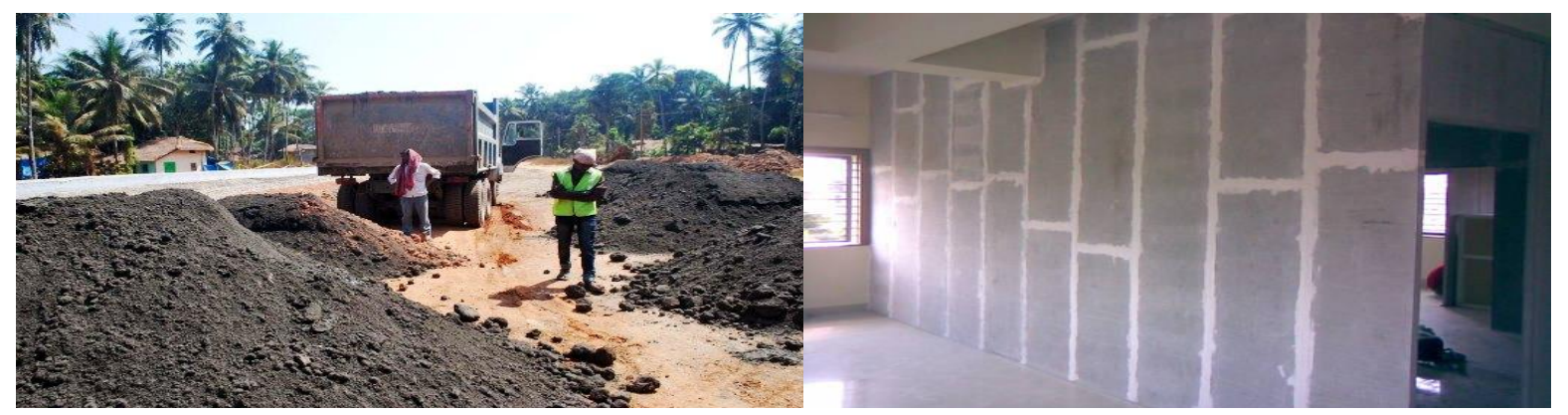

Fig 23: A typical view of fly ash [76]

Fig 24: A typical view of Aerocon panels [77] 